\section{The Information and Communication Technology (ICT) faculty relief project: An assignment algorithm for secondary schools' operations management}

Loso, Maricris M.

Leyte Normal University, Philippines (cris_gamar@yahoo.com)

Received: 5 November 2021

Available Online: 2 January 2022
Revised: 29 November 2021 DOI: $10.5861 /$ ijrse.2022.204

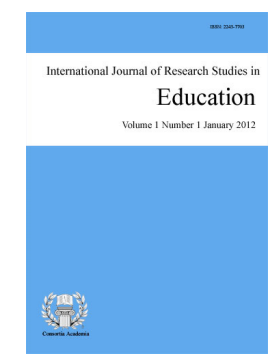

ISSN: $2243-7703$ Online ISSN: 2243-7711

Accepted: 20 December 2021

OPEN ACCESS

\title{
Abstract
}

This study aims to determine the impact of recruitment and selection process of substitute teachers to the academic performance of the senior high school students' in Information and Communication Technology enrolled in a school in Samar, Philippines. Using the purposive sampling technique and appropriate statistical tools, findings revealed that the skills required for each specialized learning area (subject) in the ICT strand are centered on database management and programming, entrepreneurship, and management of systems and technology. Moreover, specialization, teaching schedule, and teaching load are effective measures to properly evaluate the cost of assigning teaching personnel to relieve an absentee faculty member. It was recommended that these findings may serve as baseline information to properly plan the hiring of manpower or human resource manpower.

Keywords: information and communication technology, human resource management, assignment algorithm, academic performance, senior high school 


\section{The Information and Communication Technology (ICT) faculty relief project: An assignment algorithm for secondary schools' operations management}

\section{Introduction}

Amidst the economic development brought about by the movement towards globalization, the unification of the ASEAN market, international trade, and free-flowing of goods and services, competition among prospective employees has stiffened even more. The Philippines only earned \$3,000 per capita income in 2016, making it the $49^{\text {th }}$ Association of Southeast Asian Nations (ASEAN) in adventure, citizenship, cultural influence, entrepreneurship, and heritage. Although the country is growing at an average of $6 \%$ in its GDP per capita, it will take years before the Philippines can catch up with its neighboring countries. One of the solutions to accelerate the country's competitiveness index is investing and improving its human development index through better goods and services available in the market. These would ultimately yield higher standards of living (US News, 2017).

One of the Philippines' government investments for education is two more years for senior high school. Graduates of the senior high school tracks are expected to be equipped with the necessary tools to become effective workers in their respective communities. However, it has been observed that learning facilitators handling this level have tendencies not to hold classes for a myriad of reasons, which, in turn, would negatively affect student performance. These reasons include missing too many lectures and living in crowded households. These conditions could ultimately affect students' performance. Another factor that affects students' performance is teachers' absenteeism. Presently, there is no provision or official guidelines for relieving teachers to fill faculty absences in public schools. This situation leads to either an interrupted learning process, in cases where the classes are left without a learning facilitator, or a reduced quality education, where random faculty members are chosen to relieve the absent personnel (Harb, 2006).

Present studies on teacher absenteeism have addressed the problem by understanding why these teaching-personnel miss school. For example, Finlayson (2009) stressed that teachers' absences disrupt student learning and, when observed repeatedly, impacts student performance negatively. As such, an incentive program can prevent them from committing this phenomenon. In the country, literature relative to absenteeism suggests that students commit more absences than the teachers and administrative staff, leading to demotivation to pursue higher education and even continue their studies (Elis, 2009).

Researchers both abroad and in the country sought to address the absenteeism problem by attempting to resolve the root causes. These attempts, however, failed to improve the status of the phenomenon, such as in the case of Dolores National High School. This study endeavors to bridge the gap of maintaining or improving learners' academic performance by choosing the right personnel to handle absentee faculty classes. This involves a process similar to human resource managers' recruitment and selection process, precisely the selection criteria. This includes general skills and knowledge, characteristics and traits, and special considerations, which may include: motivation, dependability, good time management, prioritization skills, and the ability to work efficiently without close supervision (Lohrey, 2017).

Considerably, the selection criteria enable the company to save resources that could otherwise be used to foster growth in an organizational setup. The same efficiency and effectiveness are sought after in the auto-assignment function of the algorithm. This present undertaking strives to address the concerns of faculty absences and mitigate its impact on students' learning through student performance by auto-selecting a learning facilitator who has the necessary skills, background, and availability to handle the classes, ensuring that the learning process of all students is uninterrupted. So, it aims to improve student performance in the ICT strand amidst teacher absences by generating an assignment algorithm that could auto-assign the most qualified ICT 
The ICT faculty relief project: An assignment algorithm for secondary schools' operations management

faculty to fill in at Dolores National High School, Dolores, Eastern Samar. Precisely, this paper will ascertain the skills required for each topic of all ICT learning areas as mandated by the Department of Education for A.Y. 2019-2020, formulate the linear programming algorithm to auto-assign ICT faculty personnel in terms of specialization, teaching schedule, and teaching load; as well as assess the effectiveness of the algorithm in terms of ICT student performance.

\section{Methods}

This section presents the participant characteristics, sampling technique, research design, methods of data gathering, as well as the statistical treatment and methods of analysis of the data.

\subsection{Participant Characteristics}

This study relies heavily on the number of sections available for grades 11 and 12. The nature of this research requires a clear establishment of the cause-and-effect relationship between the method of faculty relief applied and class performance. It is primarily why only the grade 12 students were selected to participate in the study, considering that they are currently only one section for grade 11 ICT learners. For ethical considerations, the participants were asked to sign an informed consent to express their willingness to participate and that those who refuse to do so were not forced to take part of the study. Additionally, all personal information were withheld and that utmost confidentiality of the data was assured to them.

\subsection{Sampling Procedures}

Sampling Technique - This study made use of purposive sampling techniques. The technique was chosen in consideration of the nature of the study. For this purpose, 62 participants were utilized as samples.

Research Design - This study relied on the experimental research design in analyzing the data collected from the students and faculty members of the Technical Vocational Track - Information, Communications, and Technology strand in Dolores National High School; through archival research (secondary data collection) and observation (primary data collection). This study has two phases. Phase one is centered on developing the assignment algorithm through linear programming. The researcher utilized secondary data collection to generate the values needed in the cost matrix. The following formula was used to compute the cost values:

\section{Cost Value $=\mathrm{L} \times \mathrm{T} \times \mathrm{S}$}

where

$\mathrm{L}=$ teaching load; expressed in number of hours of teaching per week

$\mathrm{T}=$ specialization; expressed in values ranging from

1. teaches the same subject as the faculty to be relieved;

2. teaches a subject related to the subject of the faculty to be relieved; or

3. does not teach the same or related subject as the faculty to be relieved

$\mathrm{S}=$ teaching schedule; expressed in values ranging from

1. is available for the time slot of the faculty to be relieved; or

2. is partially available for the time slot of the faculty to be relieved

Meanwhile, phase two is focused on testing the effectiveness and applicability of the model. In order to properly establish the cause-and-effect relationship between assigning the right personnel using the assignment algorithm, and the increase/ decrease in the score, this study mainly utilizes the measures of central tendency (mean) to analyze the results of the experiment at different time intervals. It follows the basic format: 
Figure 1. Classic Experiment Diagram

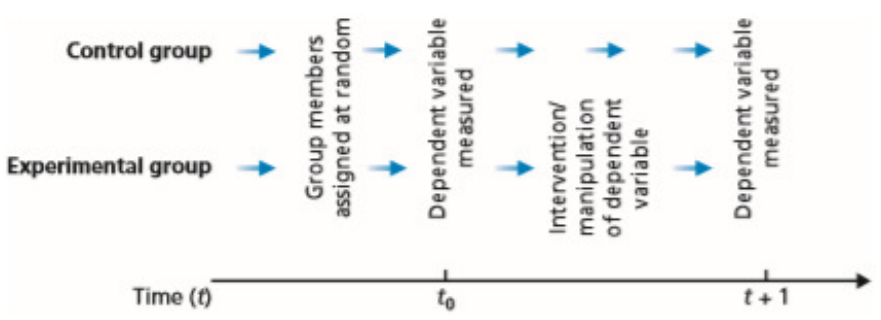

As an exploratory research, this study uses both quantitative measures and data to evaluate the effectiveness of the algorithm to be developed, as well as qualitative data, to provide additional details to provide new insights to the phenomenon of ineffective management of teachers' absences and its effect on student performance.

\section{Dataset Structure}

Algorithm Formula

\section{Objective Function}

$$
\text { Minimize } Z=\sum_{j=1}^{n} \sum_{i=1}^{n} C_{i j} X_{i j}
$$

$$
\begin{aligned}
& \text { Constraints } \\
& \qquad \begin{array}{r}
\sum_{j=1}^{n} X_{i j}=1 \\
\sum_{i=1}^{n_{i j}} X_{i j}=1 \\
X_{i j}=1 \\
X_{i j}=0
\end{array}
\end{aligned}
$$$$
\mathrm{i}=1,2 \ldots \mathrm{n}
$$$$
\mathrm{j}=1,2 \ldots \mathrm{n}
$$$$
\text { if the job } i \text { is assigned to the machine } j
$$$$
\text { other wise }
$$

Controlled Variables - These include the subject topics - covered by the two sections under the ICT program during the testing period; and the class size — of which both classes had a size of 31 individuals.

Independent Variable - The sole variable was the facilitator-in-charge. This refers to the teacher assigned to facilitate learning the subject topics. The control group was handled by the appointed faculty member of Dolores National High School, and the assigned faculty member handled the experimental group according to the assignment algorithm.

Dependent Variable - The sole variable was the performance rating. It refers to the score (expressed in percentage) attained by each participant of the algorithm testing. The average rating of a class would serve as an indicator of whether the assignment algorithm was effective or not. A greater than or equal to the average rating from the experimental group (after testing) would mean that the assignment algorithm could adequately assign the correct faculty member to relieve the absentee teaching personnel.

Statistical Treatment - The data collected were tabulated first by case, then subdivided into the control group experimental group (before testing), an experimental group (after testing). The analysis was guided by averaging, tally, and percentage methods.

\section{Results and Discussion}

The table shows the cost matrix developed for the assignment algorithm. It displays all faculty members assigned for the ICT strand's specialized subjects. The values indicated are arranged per time slot, per day, and follow the formula $\mathrm{C}=\mathrm{L} \times \mathrm{T}$ x $\mathrm{S}$. 
The ICT faculty relief project: An assignment algorithm for secondary schools' operations management

Table 1

Cost Matrix

\begin{tabular}{|c|c|c|c|c|c|c|c|c|c|c|c|c|c|}
\hline & & & & $\mathbf{A}$ & B & $\mathrm{C}$ & D & $\mathbf{E}$ & $\mathbf{F}$ & $\mathbf{G}$ & $\mathbf{H}$ & I & $\mathbf{J}$ \\
\hline \multirow{14}{*}{ MONDAY } & $\begin{array}{l}\text { 7:00AM-7:30 } \\
\text { AM }\end{array}$ & & & & & & & & & & & & \\
\hline & $\begin{array}{l}\text { 7:30AM-8:30 } \\
\text { AM }\end{array}$ & \multirow[t]{2}{*}{$\begin{array}{l}\text { ANIMA } \\
\text { TION }\end{array}$} & $\begin{array}{l}\text { COMPU } \\
\text { TER } \\
\text { SYSTE } \\
\text { MS } \\
\text { SERVIC } \\
\text { ING } \\
\end{array}$ & 20 & $X$ & $X$ & X & X & X & X & 75 & $X$ & X \\
\hline & $\begin{array}{l}\text { 8:30AM-8:45 } \\
\text { AM }\end{array}$ & & \multirow{2}{*}{$\begin{array}{l}\text { COMPU } \\
\text { TER } \\
\text { SYSTE } \\
\text { MS } \\
\text { SERVIC } \\
\text { ING }\end{array}$} & 120 & X & X & X & X & $\mathrm{X}$ & $\mathrm{X}$ & 75 & 15 & $X$ \\
\hline & $\begin{array}{l}\text { 8:45AM-9:30 } \\
\text { AM }\end{array}$ & & & X & X & 34 & X & X & X & $\begin{array}{l}10 \\
2\end{array}$ & $X$ & 15 & $X$ \\
\hline & $\begin{array}{l}\text { 9:30AM-9:45 } \\
\text { AM }\end{array}$ & & & & & & & & & & & & \\
\hline & $\begin{array}{l}\text { 9:45AM-10:4 } \\
\text { 5AM }\end{array}$ & $\begin{array}{l}\text { ANIMA } \\
\text { TION } \\
/ \\
\text { COMPU } \\
\text { TER } \\
\text { SYSTE } \\
\text { MS } \\
\text { SERVIC } \\
\text { ING }\end{array}$ & & $\begin{array}{l}20 \text { or } \\
60\end{array}$ & $X$ & $X$ & 80 & 60 & $\begin{array}{l}12 \\
0\end{array}$ & 51 & $X$ & 15 & $X$ \\
\hline & $\begin{array}{l}\text { 10:45AM-11: } \\
\text { 45AM }\end{array}$ & \begin{tabular}{l} 
ANIMA \\
TION \\
\multicolumn{1}{c}{$/$} \\
COMPU \\
TER \\
SYSTE \\
MS \\
SERVIC \\
ING
\end{tabular} & & $X$ & $X$ & $X$ & 40 & 60 & 60 & 51 & $X$ & 15 & $X$ \\
\hline & $\begin{array}{l}\text { 12:00PM-1:00 } \\
\text { PM }\end{array}$ & & & & & & & & & & & & \\
\hline & $\begin{array}{l}\text { 1:00PM-2:00 } \\
\text { PM }\end{array}$ & $\begin{array}{l}\text { COMPU } \\
\text { TER } \\
\text { SYSTE } \\
\text { MS } \\
\text { SERVIC } \\
\text { ING }\end{array}$ & & $X$ & X & 17 & 40 & $X$ & $X$ & 51 & $X$ & 15 & $\mathrm{X}$ \\
\hline & $\begin{array}{l}\text { 2:00PM-3:00 } \\
\text { PM }\end{array}$ & & & & & & & & & & & & \\
\hline & $\begin{array}{l}\text { 3:00PM-3:30 } \\
\text { PM }\end{array}$ & & & & & & & & & & & & \\
\hline & $\begin{array}{l}\text { 3:30PM-4:00 } \\
\text { PM }\end{array}$ & \multirow{2}{*}{$\begin{array}{l}\text { TECHNI } \\
\text { CAL } \\
\text { DRAFTI } \\
\text { NG } \\
\end{array}$} & \multirow{3}{*}{$\begin{array}{l}\text { COMPU } \\
\text { TER } \\
\text { SYSTE } \\
\text { MS } \\
\text { SERVIC } \\
\text { ING }\end{array}$} & \multirow{2}{*}{$X$} & \multirow{2}{*}{60} & \multirow{2}{*}{$X$} & \multirow{2}{*}{$\mathrm{X}$} & \multirow{2}{*}{60} & \multirow{2}{*}{60} & \multirow{2}{*}{$X$} & \multirow{2}{*}{$X$} & \multirow{2}{*}{15} & \multirow{2}{*}{$X$} \\
\hline & $\begin{array}{l}\text { 4:00PM-4:45 } \\
\text { PM }\end{array}$ & & & & & & & & & & & & \\
\hline & $\begin{array}{l}\text { 4:45PM-5:00 } \\
\text { PM }\end{array}$ & & & $X$ & 60 & 17 & $X$ & 60 & 60 & $X$ & $X$ & 15 & $\mathrm{X}$ \\
\hline \multirow[b]{2}{*}{$\begin{array}{l}\text { TUESDA } \\
\mathrm{Y}\end{array}$} & $\begin{array}{l}\text { 7:00AM-7:30 } \\
\text { AM }\end{array}$ & & & & & & & & & & & & \\
\hline & $\begin{array}{l}\text { 7:30AM-8:30 } \\
\text { AM }\end{array}$ & $\begin{array}{l}\text { ANIMA } \\
\text { TION }\end{array}$ & $\begin{array}{l}\text { COMPU } \\
\text { TER } \\
\text { SYSTE } \\
\text { MS } \\
\text { SERVIC }\end{array}$ & 20 & 60 & $X$ & 60 & $X$ & X & $X$ & 75 & $\mathrm{X}$ & $\mathrm{X}$ \\
\hline
\end{tabular}




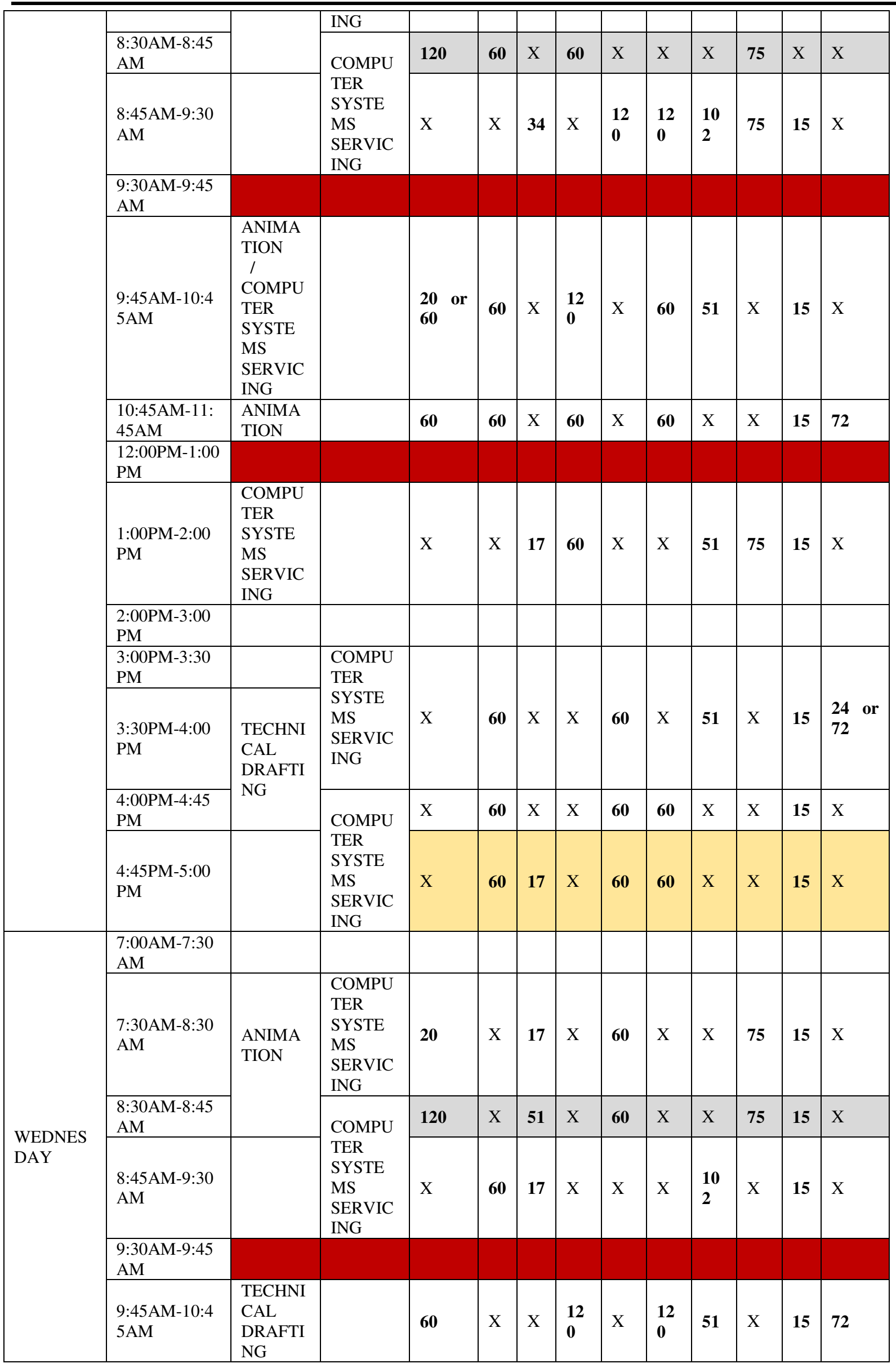

30 Consortia Academia Publishing (A partner of Network of Professional Researchers and Educators) 
The ICT faculty relief project: An assignment algorithm for secondary schools' operations management

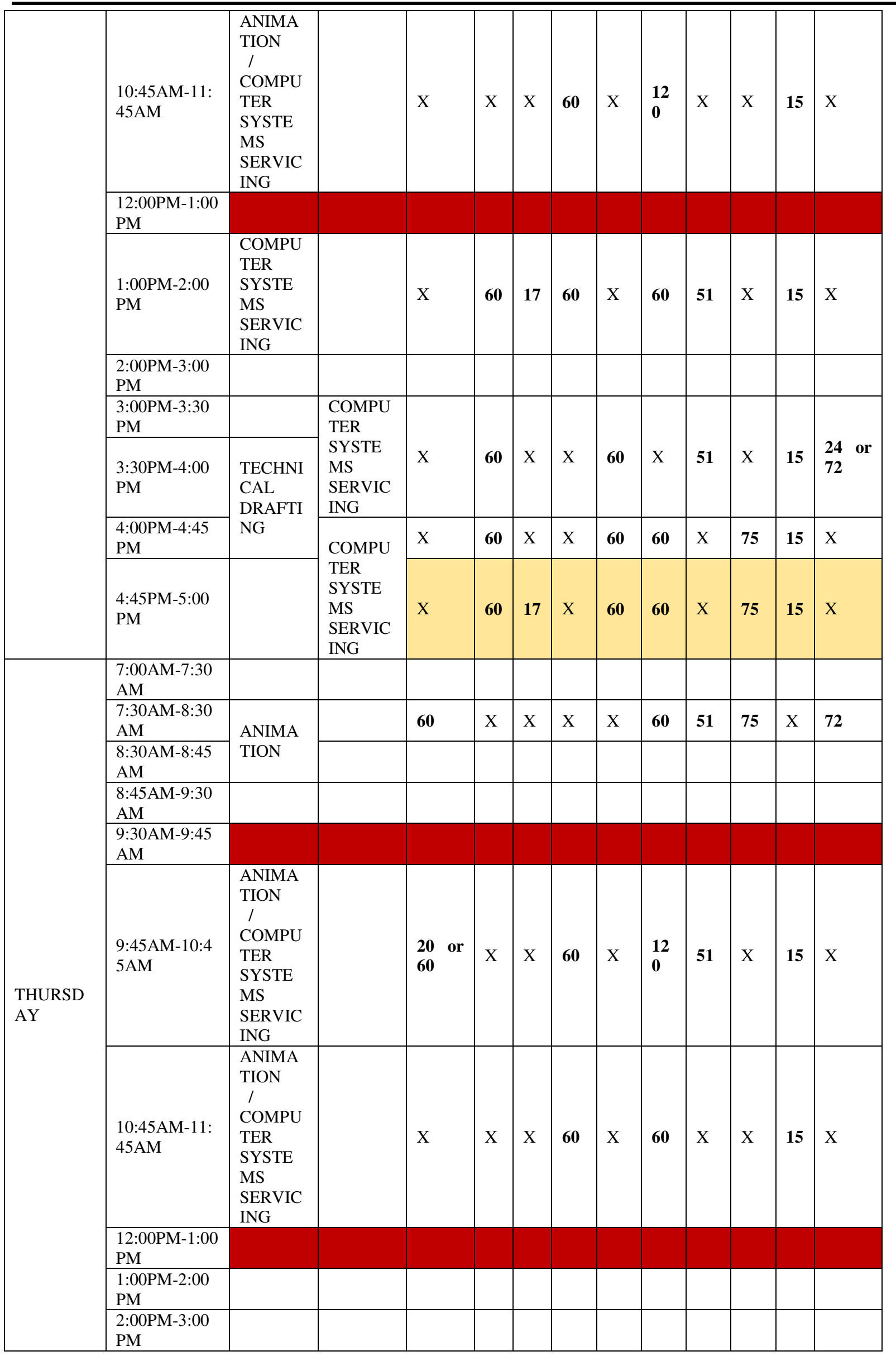




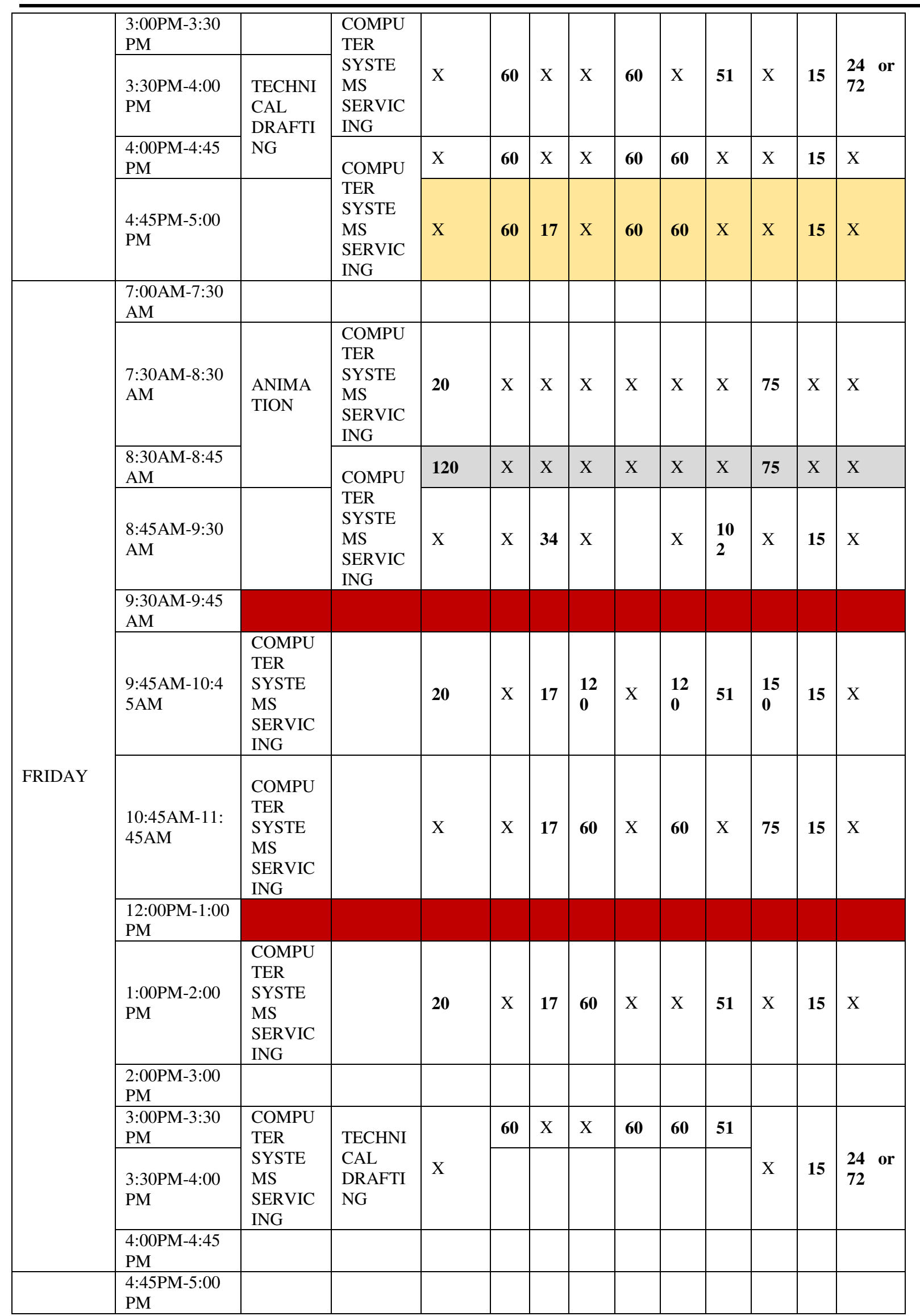

This cost matrix was used to assign the most appropriate subject-handler during the experimentation. Table 2 , shows the results of the experiment with 62 participants. The data collected were taken from two, time 
The ICT faculty relief project: An assignment algorithm for secondary schools' operations management intervals; with both control and experimental group being tested in their knowledge on Computer Systems Servicing: Setting up Computer Servers Each grade 12 section of the ICT strand were randomly assigned as the control group and the experimental group. The assignment was retained for both case one and case two.

Table 2

Experiment Results Case 1

\begin{tabular}{|c|c|c|}
\hline \multirow[b]{2}{*}{ Control Group (CG) } & \multicolumn{2}{|c|}{ Experimental Group (EG) } \\
\hline & Before Testing & After Testing \\
\hline 61 & 67 & 70 \\
\hline 63 & 44 & 26 \\
\hline 85 & 46 & 34 \\
\hline 49 & 72 & 100 \\
\hline 64 & 70 & 90 \\
\hline 32 & 75 & 90 \\
\hline 71 & 59 & 80 \\
\hline 80 & 78 & 100 \\
\hline 48 & 61 & 100 \\
\hline 50 & 42 & 100 \\
\hline 75 & 56 & 50 \\
\hline 68 & 74 & 100 \\
\hline 63 & 63 & 100 \\
\hline 65 & 72 & 40 \\
\hline 80 & 63 & 100 \\
\hline 63 & 47 & 24 \\
\hline 67 & 76 & 100 \\
\hline 67 & 65 & 100 \\
\hline 47 & 70 & 90 \\
\hline 81 & 76 & 46 \\
\hline 80 & 59 & 50 \\
\hline 74 & 53 & 70 \\
\hline 80 & 54 & 70 \\
\hline 46 & 68 & 50 \\
\hline 81 & 76 & 46 \\
\hline 80 & 59 & 50 \\
\hline 55 & 80 & 100 \\
\hline 72 & 75 & 100 \\
\hline 64 & 73 & 56 \\
\hline 67 & 59 & 20 \\
\hline 45 & 73 & 60 \\
\hline Total: 63.72 & 63.84 & 67.06 \\
\hline
\end{tabular}

At the first stage of the experiment, both groups were handled by the faculty-in-charge resulting in average rates of $63.72 \%$ and $63.84 \%$ for the control group and experimental group respectively. The second stage of the experiment then introduced a new faculty, selected by the assignment algorithm, to handle the experimental group. They were then tested with the same questionnaire, and yielded an average score of $67.06 \%$.

Table 3

Summary of Results (Case 1)

\begin{tabular}{llll}
\hline Case 1 & & & \\
\hline & $\mathrm{CG}$ & $\begin{array}{l}\text { EG } \\
\text { (before testing) }\end{array}$ & $\begin{array}{l}\text { EG } \\
\text { (after testing) }\end{array}$ \\
\hline Mean Score & 63.72 & 63.84 & 67.06 \\
\hline $\begin{array}{c}\text { \% Difference } \\
\text { before and after }\end{array}$ & $5 \%$ & & \\
$\begin{array}{c}\% \text { Difference } \\
\text { CG and EG }\end{array}$ & $5 \%$ & & \\
\hline
\end{tabular}

Case one thus displays that the assignment algorithm successfully selected the correct faculty member to relieve the absentee teacher, showing an increase of 5\% from before the test was administered. It should be noted that there was an increase in the experimental group's performance from the control group by $5 \%$. This is an 
Loso, M. M.

indicator that the participants understood the topic better.

\section{Table 4}

Experiment Results Case 2

\begin{tabular}{ccc}
\hline & \multicolumn{2}{c}{ Experimental Group (EG) } \\
Control Group $(\mathrm{CG})$ & Before Testing & After Testing \\
\hline 66 & 90 & 90 \\
100 & 50 & 85 \\
60 & 64 & 71 \\
81 & 70 & 64 \\
100 & 100 & 93 \\
79 & 43 & 100 \\
100 & 50 & 100 \\
100 & 80 & 100 \\
63 & 74 & 80 \\
43 & 100 & 79 \\
79 & 100 & 80 \\
50 & 70 & 79 \\
100 & 100 & 53 \\
63 & 100 & 100 \\
100 & 30 & 71 \\
74 & 100 & 74 \\
68 & 90 & 100 \\
64 & 60 & 80 \\
100 & 40 & 80 \\
69 & 70 & 100 \\
93 & 90 & 53 \\
\hline Total: & 72.50 & 71.34 \\
\hline
\end{tabular}

Case two follows the same setup as case one; however, the participants are tested on their knowledge on Maintaining and Repairing Computer Systems and Networks (MRCN). Stage one results of case two show a score of $72.5 \%$ for the control group and $71.34 \%$ for the experimental group. The second stage of case two increased the average score of the experimental group, reaching $81.66 \%$.

Table 5

Summary of Results (Case 2)

\begin{tabular}{llll}
\hline Case 2 & & & EG \\
& CG & $\begin{array}{l}\text { EG } \\
\text { (before testing) }\end{array}$ & 81.66 \\
\hline Mean Score & 72.5 & 71.34 & \\
\hline $\begin{array}{l}\% \text { Difference } \\
\text { before and after }\end{array}$ & $14 \%$ & & \\
\hline $\begin{array}{l}\text { Difference } \\
\text { CG and EG }\end{array}$ & $13 \%$ & & \\
\hline
\end{tabular}

Case two likewise indicates that the assignment algorithm effectively selected the right faculty member to relieve the absentee teacher, increasing by $14 \%$. A $13 \%$ higher rating can also be observed between the scores of the control group and experimental groups' scores (after testing).

\section{Table 6}

Summary of Results (Both Cases)

\begin{tabular}{ccc}
\hline & $\begin{array}{c}\% \text { Difference } \\
\text { before and after testing }\end{array}$ & $\begin{array}{c}\text { \% Difference CG } \\
\text { and EG (after testing) }\end{array}$ \\
\hline Case 1 & $5 \%$ & $5 \%$ \\
Case 2 & $14 \%$ & $13 \%$ \\
Average & $10 \%$ & $9 \%$ \\
\hline
\end{tabular}

The table shows a summary of the positive increases to the scores of the experimental group after the assignment algorithm was used to auto-assign a faculty member.

34 Consortia Academia Publishing (A partner of Network of Professional Researchers and Educators) 


\section{Conclusions}

Based on the findings, the following conclusions are drawn. The skills required for each specialized learning area (subject) in the ICT strand are centered on database management and programming, entrepreneurship, and management of systems and technology. Moreover, specialization, teaching schedule, and teaching load are effective measures to properly evaluate the cost of assigning teaching personnel to relieve an absentee faculty member. This is due to the cost values accounting for the teacher's availability, skill fit, and energy or capacity to facilitate the class's learning. Finally, there is sufficient data to conclude that the assignment algorithm can effectively assign the right substitute academic personnel to handle unsupervised classes due to faculty absences, using the factors of specialization, teaching load, and teacher availability in its decision criteria. In addition, a higher average score characterizes the model's effectiveness by $9 \%$ in the learning area of Business Finance of the experimental group compared with the control group.

\section{Recommendations}

Given the findings above, it is thus recommended that the increase in the academic performance of the students in the Senior High School ICT strand as a result of the implementation of the assignment algorithm necessitates the conduct of further experimental studies on the effect of its application to the other strands (Home Economics, Agri-Fishery Arts, and Industrial Arts). Additionally, despite the previous positive result brought by the use of the assignment algorithm, there is another criterion that it fails to measure-the willingness of a teacher to serve as a substitute. Thus, further studies may be conducted, including the teacher's willingness as an additional criterion in improving the assignment algorithm. The relevance of this criterion is supported by studies that account for willingness as a factor that improves teacher performance.

\section{References}

Center for Innovation in Research Training (n.d.). Retrieved from http://cirt.gcu.edu/research/development resources/research ready/phenomenology/phen_overview

Ellis, J. (2009). Effects of Absenteeism to the Learning Performance of Fourth Year Students of one National High School in Batangas City Philippines. Retrieved from academia: http://www.academi.edu/32971807

Finlayson, M. (2009). The impact of teacher absenteeism on student performance: The Case of the Cobb County School District. Retrieved from https://www.researchgate.net/publication/237534692

Harb, N. (2006). Factors affecting students' performance. Retrieved from Research Gate https://www.researchgate.net/publication/24112529

Kenton, W. (2018). How the Philippines Compete globally? Retrieved from Investopedia//www.investopedia.com/terms/g/globalization.asp

Lohrey, J. (2017). Criteria Employee Selection. Retrieved from https://bizfluent.com/about-7229225-criteria-employee-selection.html

Luistro, A., Licuanan, D., \& Villanueva, J. (2013). Implementing Rules and Regulations of the Enhanced Basic Education Act of 2013. Retrieved from Official Gazette https://www.officialgazette.gov./2013/09/04/irrepebulic-act-no-10533

Martinez, S., \& Miller, R. (2018, November 26). EdSource. Retrieved from https://edsource.org/2018/measuring-growth-in-test-scores-is-key-to-understanding-student-progress/60 4959

McMahon, J. M. (2015). Which statistical test is used to analyzed cause and effect relationship between two variables independent of any grouping variables.

Saunders, M., Lewis, P., \& Thornhill, A. (2009). Research Methods for Business Students 5th ed. Prentice Hall. 
Loso, M. M.

36 Consortia Academia Publishing (A partner of Network of Professional Researchers and Educators) 